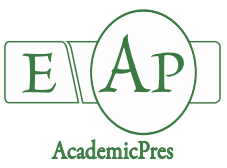

Garza-Alonso CA et al. (2020)

Notulae Botanicae Horti Agrobotanici Cluj-Napoca 48(3):1585-1599

DOI: $10.15835 /$ nbha48311867

Research Article

\title{
Physicochemical characteristics, minerals, phenolic compounds, and antioxidant capacity in fig tree fruits with macronutrient deficiencies
}

\author{
Carlos A. GARZA-ALONSO ${ }^{1}$, Guillermo NIÑO-MEDINA ${ }^{1}$, \\ Adriana GUTIÉRREZ-DÍEZ ${ }^{1}$, Josué I. GARCÍA-LÓPEZ², \\ Rigoberto E. VÁZQUEZ-ALVARADO ${ }^{1}$, Alfredo LÓPEZ-JIMÉNEZ ${ }^{3}$, \\ Emilio OLIVARES-SÁENZ ${ }^{1 *}$
}

\begin{abstract}
${ }^{1}$ Universidad Autónoma de Nuevo León, Facultad de Agronomía, Francisco Villa s/n col. ExHacienda el Canadá, Gral. Escobedo, N.L.,México; carlos.garza.alonso@gmail.com; emolivares@gmail.com (*correspondingauthor); guillermo.ninomd@uanl.edu.mx; mcgudiez@aol.com; rvazquez.alvarado@gmail.com

${ }^{2}$ Universidad Autónoma Agraria Antonio Narro, Departamento de Fitomejoramiento, Centro de capacitación y desarrollo en tecnología de semillas, Calzada Antonio Narro 1923 col. Buenavista, Saltillo, Coah., México; g.lopezj90@gmail.com

${ }^{3}$ Colegio de Postgraduados, Recursos Genéticos y Productividad-Fruticultura, Carretera México-Texcoco Km 36.5, Montecillo, Texcoco, Edo. de Méx., México; lopezja@colpos.mx
\end{abstract}

\begin{abstract}
In this research, effects of macronutrient deficiency $(\mathrm{N}, \mathrm{P}, \mathrm{K}, \mathrm{Ca}$, and $\mathrm{Mg}$ ) on the production, physicochemical characteristics, minerals, phenolic compounds, and antioxidant capacity of fig fruits (Ficus carica L.) were evaluated using the missing element technique in a controlled hydroponic system under greenhouse conditions. N-deficient plants had no fruit production, while fruits with absence of $\mathrm{P}, \mathrm{K}$, and $\mathrm{Ca}$ were the most affected in terms of size, weight, and physicochemical characteristics. On the other hand, the concentration of minerals was significantly different $(p<0.05)$, finding some interactions of synergism and antagonism between ions. Phenolic compounds increased in fruits with $\mathrm{P}$ and $\mathrm{Ca}$ deficiency, as well as the antioxidant capacity DPPH (2,2-diphenyl-1-picrylhydrazyl) and ABTS (2,2'azino-bis (3ethylbenzothiazoline-6-sulfonic acid)) in the fruits of the treatment -Ca. Regarding the FRAP (ferric reducing antioxidant power) test, higher values were found for all treatments without minerals $(-\mathrm{P},-\mathrm{K},-\mathrm{Ca}$, and $-\mathrm{Mg})$ with respect to the control. The results obtained explain the responses of the fig tree subjected to nutritional deficiencies.
\end{abstract}

Keywords: condensed tannins; Ficus carica L.; flavonoids; fruit quality; plant nutrition

\section{Introduction}

The fig tree (Ficus carica L.) is a deciduous plant native to the Mediterranean region, whose cultivation has been increasing in recent years (FAO, 2019). The fruits are appreciated for their high commercial value (USDA, 2019), high sugar content (Crisosto et al., 2010), as well as high phenolic compounds and antioxidant power (Vallejo et al., 2011; Harzallah et al., 2016). Furthermore, various studies have found that fig leaves have 
hypoglycemic properties (Deepa et al., 2018); the fruits, roots, stems, and leaves of the plant have other beneficial effects such as anticancer and antiseptic properties (Badgujar et al., 2014).

Plant nutrition is one of the most important factors for crop production. Nutrients play specific functions in plants, when these elements are at low levels, certain specific physiological processes are affected, such as photosynthesis and cellular respiration (Karthika et al., 2018); therefore, nutritional deficiencies affected vegetative growth, production, and fruit quality, specifically the absence of nitrogen $(\mathrm{N})$, phosphorus $(\mathrm{P})$, potassium $(\mathrm{K})$, calcium $(\mathrm{Ca})$, and magnesium $(\mathrm{Mg})$ (Pandey, 2015). The missing element technique allows studying the effects of nutrient deficiency; this experimental method consists in removing from the nutrient solution the element to be analyzed (Kathpalia and Bhatla, 2018). This technique has been used in different species, such as the work reported by Mota and Rocha (2014), who found that the size and weight of pineapple fruits (Anana comosus) decreased when the plants suffered some deficiencies of N, P, and K in a 57.59, 26.78, and 22.8\%, respectively. The same study found a 200\% increase in Vitamin C content in N-deficient fruits, compared to full fertilization. On the other hand, Nava et al. (2008) studied the effects of $\mathrm{N}$ and $\mathrm{K}$ deficiencies in apples, finding negative effects on some physicochemical parameters, such as titratable acidity and ${ }^{\circ} \mathrm{Brix}$, which increased linearly with increasing doses of these elements. Furthermore, various authors have reported the effects of macronutrient suppression on the concentration of phenolic compounds and antioxidant capacity in plants such as Lens culinaris (Chandra and Karmoker, 2011), Daucus carota (Singh et al., 2011), and Morus alba (Kumar et al., 2007), finding differences between species.

For the fig tree, Garza-Alonso et al. (2019) reported the effects of deficiency of N, P, K, Ca, and Mg on the vegetative growth and minerals concentration in leaf, root, and stem; however, few studies have been conducted on the effects of macronutrient deficiencies in the quality of fig fruits. Esref et al. (2008) studied the effects of different doses of $\mathrm{Ca}$, where the average fruit weight decreased from 16.24 to $14.43 \mathrm{~g}$ when this element was not applied, which also produced a 34\% reduction in yield per plant. In other studies, Soliman et al. (2018) carried out similar evaluations with $\mathrm{K}$, finding a reduction of $28.2 \%$ in fruit weight and $10.34 \%$ in the total soluble solids content when $\mathrm{K}$ was absent in the nutrient solution. On the other hand, Holstein et al. (2017) reported an $18.7 \%$ reduction in fruit yield between plants with and without applications of K. Gaaliche et al. (2019) evaluated the effects of the foliar application of $\mathrm{K}$ against the non-application of the same element on the concentration of phenolic compounds, finding a decrease of $14.33 \%$ in the content of total phenols, $48 \%$ reduction for total flavonoids, as well as a $34.44 \%$ increase in the antioxidant capacity DPPH by not applying $\mathrm{K}$. For $\mathrm{N}, \mathrm{P}$, and $\mathrm{Mg}$, the available information is very limited, and in most cases, not enough variables are reported to allow decisions to be made and results to be concluded.

Based on the above, the objective of the present investigation was to evaluate the effects of deficiency of $\mathrm{N}, \mathrm{P}, \mathrm{K}, \mathrm{Ca}$, and $\mathrm{Mg}$ on production, physicochemical characteristics, mineral content, phenolic compounds concentration, and antioxidant capacity of fig fruits.

\section{Materials and Methods}

\section{Experiment location and plant material}

The experiment was carried out under controlled conditions in a greenhouse, with an area of $1,000 \mathrm{~m}^{2}$ and $4.5 \mathrm{~m}$ in height at the lateral sides, its highest part being $7 \mathrm{~m}$. The average daily temperature was $25^{\circ} \mathrm{C}$ and a relative humidity of $75 \%$. The plants correspond to the 'Adriatic' cultivar, the fruit is white (ripening with green epicarp) and dark red flesh. The size is medium, approximate average weight of $30 \mathrm{~g}$.

\section{Induction of nutritional deficiencies}

The missing element technique was used to induce nutritional deficiencies in plants, which consisted of removing the element under study from the nutrient solution for each case $(-\mathrm{N},-\mathrm{P},-\mathrm{K},-\mathrm{Ca},-\mathrm{Mg})$. The substrate used was perlite, an inert material with a neutral $\mathrm{pH}$ and without mineral nutrient content (Papadopoulos et 
al., 2008). The experimental unit consisted of a $19 \mathrm{~L}$ pot with a single-stemmed plant. The root system was washed with distilled water to remove the remains of soil before placing the plants in the pots. Irrigation was supplied automatically through use of timers, applying eight daily pulses of $60 \mathrm{~mL}$ per pot. The treatments were: T1 - Complete nutritional solution (Control); T2 - Solution without nitrogen (-N); T3 - Solution without phosphorous (-P); T4 - Solution without potassium (-K); T5 - Solution without calcium (-Ca); and T6 - Solution without magnesium (-Mg).

\section{Preparation of nutritional solutions}

The nutrient solution proposed by Hewitt was selected for the preparation of the nutritional solutions, which was evaluated in the fig tree by Sevil et al. (2007). The nutrient solution consisted of the following element concentrations ( $\left.\mathrm{mg} \mathrm{L}^{-1}\right)$ : N 168, P 41, K 156, Ca 160, Mg 36, S 48, Fe 2.8, Mn 0.55, B 0.54, Cu 0.064, $\mathrm{Zn} 0.065$, and Mo 0.048 . The preparation of the solutions was carried out using rainwater, with an electrical conductivity of $0.05 \mathrm{dS} \mathrm{m}^{-1}$. The water analysis did not identify minerals that affected the investigation. For the preparation of the nutritive solutions, fertilizer sources lacking each element under study were used.

\section{Agronomic parameters and physicochemical characteristics of the fruit}

The evaluation of the agronomic parameters included: Number of fruits per plant, fresh weight, yield per plant, fruit polar and equatorial diameter.

The flesh and peel color evaluations were determined directly with a portable colorimeter (Konica Minolta BC-10, Konica Minolta, Japan). Color parameters were obtained using the CIELAB $\left(L^{*}, a^{*}, b^{*}\right)$ and CIELCH $\left(L^{*}, C^{*}, h^{*}\right)$ color systems according to the Commission Internationale De L'ecleirage (CIE, 2004). $L^{*}$ defines luminosity ( 0 black, 100 white), $a^{*}$ indicates red ( $a^{*}$ positive) or green ( $a^{*}$ negative), $b^{*}$ indicates yellow ( $b^{*}$ positive) or blue ( $b^{*}$ negative), $C^{*}$ (chroma) saturation level, and $h$ (hue angle: $0^{\circ}=$ red, $90^{\circ}=$ yellow, $180^{\circ}=$ green, $270^{\circ}=$ blue). Color visualization was obtained using the online software ColorHexa (2019) using the $L^{*}, a^{*}$, and $b^{*}$ values.

Total soluble solids content $\left({ }^{\circ}\right.$ Brix) was performed by taking a portion of the pulp, which was placed in a digital refractometer (Atago Pen-pro, Atago Inc., USA), with a range of 0-85\%. Titratable acidity was determined by weighing $5 \mathrm{~g}$ of pulp, which were processed with $40 \mathrm{~mL}$ of distilled water in a mixer (Oster blender M4655-813 / 465-42 Sunbeam, Mexico) for $30 \mathrm{~s}$. The extract was filtered through organza cloth. The $\mathrm{pH}$ was measured using a potentiometer ( $\mathrm{pH} /$ ORP Meter HI 2221, Mexico). Titratable acidity (TA) was determined by method 942.15 of the Official Association of Analytical Chemistry (AOAC, 2000), with $0.1 \mathrm{M}$ $\mathrm{NaOH}$ at $\mathrm{pH} 8.2$ using phenolphthalein as an indicator. Titratable acidity was reported as a percentage of citric acid in fresh weight $(\mathrm{g} / 100 \mathrm{~g})$.

\section{Determination of minerals}

Fruits samples were dried in a Yamato DX 602C oven (Yamato Scientific Co, Japan) at $60^{\circ} \mathrm{C}$ for $72 \mathrm{~h}$. The resulting material was crushed and subjected to acid digestion in a mixture of perchloric acid and nitric acid (Alcántar and Sandoval, 1999).

$\mathrm{N}$ was quantified by the micro Kjendahl method according to the Bremner (1965) methodology. Fruits concentrations of $\mathrm{P}, \mathrm{K}, \mathrm{Ca}, \mathrm{Mg}, \mathrm{Fe}, \mathrm{B}, \mathrm{Mn}, \mathrm{Zn}$, and $\mathrm{Cu}$ was carried out using the extract of acid digestion by means of a coupled plasma induction atomic emission spectrometer (ICP-AES Agilent 725- ES, Agilent Technologies, USA).

\section{Extraction of soluble (free) phenolic compounds}

Fruits were separated into pulp and peel and $5 \mathrm{~g}$ of sample for each part were weighed and processed in a mixer (Oster Blender M4655-813 / 465-42 Sunbeam, Mexico) with $50 \mathrm{~mL}$ of $80 \%$ methanol for $30 \mathrm{~s}$. Subsequently, the mixture was filtered with organza fabric to separate the remaining insoluble matter, which was used for the extraction of bound phenolic compounds. The resulting extract was placed in $50 \mathrm{~mL}$ Falcon 
tubes and spin at $4500 \mathrm{rpm}$ for $5 \mathrm{~min}$. The supernatant was recovered and stored in the dark at $-20^{\circ} \mathrm{C}$ to carry out measurements of phenolic compounds and antioxidant capacity.

\section{Extraction of bound phenolic compounds}

Bound phenolic compounds were removed by suspending the remaining insoluble matter in test tubes, to which $5 \mathrm{~mL}$ of $2 \mathrm{M} \mathrm{NaOH}$ was added and purged with argon for $30 \mathrm{~s}$. The mixture was then stirred for $2 \mathrm{~h}$. Subsequently, the $\mathrm{pH}$ was adjusted to 2.5 with $\mathrm{HCl}$ and centrifuged at $4500 \mathrm{rpm}$ for $5 \mathrm{~min}$. The supernatant was recovered, and the bound phenolic compounds were extracted with $5 \mathrm{~mL}$ of ethyl acetate (2 times). The ethyl acetate extracts were combined and placed on a rotavapor (Yamato RE201, Yamato, Japan) for $10 \mathrm{~min}$ to evaporate the ethyl acetate. Once evaporated, the sample was resuspended with $3 \mathrm{~mL}$ of $80 \%$ methanol. The extracts obtained from soluble and bound phenolic compounds were used for the tests of total phenols, total flavonoids, condensed tannins, and antioxidant capacity (DPPH, ABTS and FRAP) (López-Contreras et al., 2015).

\section{Determination of total phenols}

For the determination of total phenolic compounds, $0.2 \mathrm{~mL}$ of each extract was taken and mixed with $2.6 \mathrm{~mL}$ of distilled water, and $0.2 \mathrm{~mL}$ of Folin-Ciocalteu reagent. After $5 \mathrm{~min}, 2 \mathrm{~mL}$ of $7 \% \mathrm{Na}_{2} \mathrm{CO}_{3}$ was added, and the solution was stirred for $30 \mathrm{~s}$. Subsequently, the mixture was allowed to stand for $90 \mathrm{~min}$ in the dark, and the absorbance was measured at a wavelength of $750 \mathrm{~nm}$. Calculations were performed using a gallic acid calibration curve in a range of 0 to $200 \mathrm{mg} \mathrm{kg}^{-1}$. The concentration of total phenols was reported as equivalent milligrams of gallic acid per kilogram of sample $\left(\mathrm{mg} \mathrm{GAE} \mathrm{kg}^{-1}\right)$.

\section{Determination of total flavonoids}

Total flavonoids concentration was determined by means of the $\mathrm{AlCl}_{3}-\mathrm{NaNO}_{2}-\mathrm{NaOH}$ reaction, for this $0.2 \mathrm{~mL}$ of the extract was taken and $3.5 \mathrm{~mL}$ of distilled water were added. Subsequently, $0.15 \mathrm{~mL}$ of $5 \% \mathrm{NaNO}_{2}$, $0.15 \mathrm{~mL}$ of $10 \% \mathrm{AlCl}_{3}$, and $1 \mathrm{~mL}$ of $1 \mathrm{M} \mathrm{NaOH}$ were added; the above at $5 \mathrm{~min}$ intervals between each addition of reagents. The reaction was left for $15 \mathrm{~min}$, and then the absorbance was measured at $510 \mathrm{~nm}$ wavelength. Results were reported as milligrams of catechin equivalent per $\mathrm{kg}$ of sample ( $\mathrm{mg} \mathrm{CatE} \mathrm{kg}{ }^{-1}$ ), calculated from a catechin calibration curve in a range of 0 to $200 \mathrm{mg} \mathrm{kg}^{-1}$

\section{Determination of condensed tannins}

Tannin content was determined using a Vanillin- $\mathrm{H}_{2} \mathrm{SO}_{4}$ reaction, for which $0.25 \mathrm{~mL}$ of the extract, 0.65 $\mathrm{mL}$ of $1 \%$ Vanillin, and $0.65 \mathrm{~mL}$ of $25 \% \mathrm{H}_{2} \mathrm{SO}_{4}$ were taken (both were dissolved in methanol). The mixture was allowed to stand for $15 \mathrm{~min}$ at $30^{\circ} \mathrm{C}$, and the absorbance was subsequently measured at a wavelength of $500 \mathrm{~nm}$. Calculations were performed using a catechin calibration curve in a range of 0 to $200 \mathrm{mg} \mathrm{kg}^{-1}$. Results were reported as milligrams of catechin equivalent per kilogram of sample (mg CatE kg$\left.{ }^{-1}\right)$.

\section{Antioxidant capacity DPPH, ABTS and FRAP}

DPPH (2,2-dipheny l-1-picrilhydrazyl) antioxidant capacity was evaluated using a $60 \mu \mathrm{M}$ working solution in $80 \%$ methanol, which was adjusted to an absorbance of 0.99 at $517 \mathrm{~nm}$ wavelength. The test was performed by mixing $50 \mu \mathrm{L}$ of the extract with $1.5 \mathrm{~mL}$ of DPPH working solution, which was left to stand for $30 \mathrm{~min}$ in the dark, and the absorbance was determined.

The antioxidant capacity ABTS (2,2-azino-bis (3-ethylbenzothiazolin) -6-sulfonic acid)) was determined using a working solution obtained by mixing $1 \mathrm{~mL}$ of ABTS $7.4 \mathrm{mM}$ and $1 \mathrm{~mL}$ of $\mathrm{K}_{2} \mathrm{~S}_{2} \mathrm{O}_{8}$, which was left to react for 12 hours in the dark. The test was performed by adding $50 \mu \mathrm{L}$ of the extract and $1.5 \mathrm{~mL}$ of the ABTS working solution. The mixture was allowed to stand for $30 \mathrm{~min}$, and the absorbance was determined with a wavelength of $734 \mathrm{~nm}$. 
The antioxidant capacity FRAP (ferric reducing antioxidant power) was determined using a working solution prepared with $300 \mathrm{mM} \mathrm{C} \mathrm{H}_{3} \mathrm{NaO}_{2} .3 \mathrm{H}_{2} \mathrm{O}, 10 \mathrm{mM}$ TPTZ (2,4,6-tripyridyl-1,3,5-triazine, in $40 \mathrm{mM}$ $\mathrm{HCl})$, and $20 \mathrm{mM} \mathrm{FeCl}_{3} \cdot 6 \mathrm{H}_{2} \mathrm{O}$ in a 10:1:1 ratio $(\mathrm{V}: \mathrm{V}: \mathrm{V})$. The assay was performed by adding $50 \mu \mathrm{L}$ of the extract and $1.5 \mathrm{~mL}$ of the FRAP working solution. The reaction was allowed to stand for $30 \mathrm{~min}$ in the dark at $37^{\circ} \mathrm{C}$. Subsequently, the absorbance was measured at $593 \mathrm{~nm}$ wavelength. The antioxidant capacity for the DPPH, ABTS, and FRAP assays were reported in Trolox equivalent micromoles per kilogram of sample $\left(\mu\right.$ molTE $\left.\mathrm{kg}^{-1}\right)$, based on the Trolox calibration curve (6-hydroxy-2,5,7 acid, 8-tetramethylchroman-2carboxylic) in a range of 0 to $500 \mu \mathrm{mol} \mathrm{kg}^{-1}$.

\section{Experimental design and statistical analysis}

The experiment was established using a completely randomized experimental design with six treatments and three repetitions per treatment; the experimental unit was one plant per pot. The results were reported as mean \pm standard deviation, the statistically significant differences between the treatments were identified with an ANOVA, and the means of the treatments were compared by the Tukey method $(p<0.05)$, using the statistical package SPSS Statistics 21.0 (SPSS Inc., Chicago, IL, USA).

\section{Results and Discussion}

\section{Agronomic parameters}

Plants with the -N treatment did not produce fruits, therefore, only the effects of the - $\mathrm{P},-\mathrm{K},-\mathrm{Ca}$, and $\mathrm{Mg}$ treatments were studied. The analysis of variance showed significant differences $(p<0.05)$ for all the evaluated agronomic variables (Table 1 ). Fruit weight was principally affected by $\mathrm{Ca}$ deficiency, reducing by $40.3 \%(18.52 \pm 1.49 \mathrm{~g})$ compared to control $(31.01 \pm 0.86 \mathrm{~g})$. The -P treatment followed $-\mathrm{Ca}$ for reduction in fruit weight with a reduction of $33.7 \%(20.56 \pm 0.53 \mathrm{~g})$, compared to the control. Similar results were found for the number of fruits, since the -Ca treatment affected $60.7 \%$ (5.50 \pm 0.70$)$ with respect to the control (14.00 \pm 0.01 ); the same pattern was presented for the -P treatment with a decrease of $35.7 \%$, while the other treatments were not different statistically from the control. The same trend was observed for fruit yield per plant; The -Ca, $-\mathrm{P}$, and $-\mathrm{K}$ treatments presented reductions of $75.1,73.8$, and $36.1 \%$, respectively.

Table 1. Effect of macronutrient deficiencies on agronomics characteristics of fig tree fruits

\begin{tabular}{|c|c|c|c|c|c|}
\hline Treatment & $\begin{array}{c}\text { Fruit } \\
\text { weight }(\mathrm{g})\end{array}$ & $\begin{array}{c}\text { Fruit } \\
\text { number }\end{array}$ & $\begin{array}{c}\text { Yield } \\
\left(\text { g plant }^{-1}\right)\end{array}$ & $\begin{array}{c}\text { Polar } \\
\text { diameter }(\mathrm{mm})\end{array}$ & $\begin{array}{c}\text { Equatorial } \\
\text { diameter }(\mathrm{mm})\end{array}$ \\
\hline Control & $31.01 \pm 0.86 \mathrm{a}$ & $14.00 \pm 0.01 \mathrm{a}$ & $449.07 \pm 30.81 \mathrm{a}$ & $41.06 \pm 1.25 \mathrm{a}$ & $39.27 \pm 1.63 \mathrm{a}$ \\
\hline$-\mathrm{P}$ & $20.56 \pm 0.53 \mathrm{bc}$ & $9.00 \pm 2.82 \mathrm{ab}$ & $117.57 \pm 45.29 \mathrm{c}$ & $36.81 \pm 1.24 \mathrm{~b}$ & $34.02 \pm 2.47 \mathrm{ab}$ \\
\hline$-\mathrm{K}$ & $24.75 \pm 1.65 \mathrm{~b}$ & $11.50 \pm 2.12 \mathrm{a}$ & $286.79 \pm 21.17 \mathrm{~b}$ & $38.05 \pm 0.03 \mathrm{ab}$ & $35.03 \pm 0.62 \mathrm{ab}$ \\
\hline$-\mathrm{Ca}$ & $18.52 \pm 1.49 \mathrm{c}$ & $5.50 \pm 0.70 \mathrm{~b}$ & $111.72 \pm 21.78 \mathrm{c}$ & $35.94 \pm 1.54 \mathrm{~b}$ & $32.25 \pm 2.93 \mathrm{~b}$ \\
\hline$-\mathrm{Mg}$ & $31.63 \pm 0.39 \mathrm{a}$ & $13.50 \pm 0.70 \mathrm{a}$ & $409.15 \pm 41.01 \mathrm{ab}$ & $41.84 \pm 1.19 \mathrm{a}$ & $35.75 \pm 1.86 \mathrm{ab}$ \\
\hline
\end{tabular}

Values are the mean of treatments $(n=3) \pm$ standard deviation. Different letters in each column means that the treatments were statistically different (Tukey, $p<0.05$ ).

On the other hand, - $\mathrm{Ca}$ and $-\mathrm{P}$ treatments decreased the polar diameter of the fruits, the reductions were $12.8 \%(35.94 \pm 1.54 \mathrm{~mm})$ and $10.3 \%(36.81 \pm 1.24 \mathrm{~mm})$, respectively, with respect to the control $(41.06 \pm$ $1.25 \mathrm{~mm}$ ). Finally, the equatorial diameter of the fruit with the -Ca treatment reported the greatest reduction of $17.87 \%(32.25 \pm 2.93 \mathrm{~mm})$ with respect to the control $(39.27 \pm 1.63 \mathrm{~mm})$, without finding statistical differences in the other treatments (Table 1). 
The nutrient absorption curves for fig cultivation developed by Mendoza et al. (2019) showed that the plant increases the demand for $\mathrm{Ca}, \mathrm{P}$, and $\mathrm{K}$ at the beginning of fruit formation, which explains the smaller size and weight of the fruits obtained in this research.

$P$ is an important constituent of nucleic acids and ATP, so it is involved in all energy transfer reactions in cells. Furthermore, this element is involved in photosynthesis, sugar translocation, and nutrient movement in plants (Hawkesford et al., 2012; Alcántar et al., 2016; Karthika et al., 2018). The lower weight, quantity, and size of fruits in plants without $P$ are explained by the importance of this element in plant physiology.

Large amounts of $\mathrm{K}$ are found as free ion at the level of vacuoles and cytoplasm, thereby generating an osmotic pressure and thus causing cell turgor. On the other hand, $\mathrm{K}$ participates in the reactions of photosynthesis and cellular respiration, in addition to promoting an efficient translocation of photosynthates from the leaves to other organs of the plant, mainly fruits (Alcántar et al., 2016). The accumulation of photoassimilates (sucrose, glucose, and fructose) has been shown in rice plants with $\mathrm{P}, \mathrm{K}$, and Ca deficiencies (Kobayashi et al., 2013). All of the above explains the results found in the present investigation.

Soliman et al. (2018) evaluated $\mathrm{K}$ doses on the quality of fig fruits, finding a $28.2 \%$ reduction in fruit weight in the treatment without the addition of potassium fertilizers. The same trend was found in the work of Holstein et al. (2017), who reported greater size and fruit yield when applying K compared to the null application of this element, the decrease in yield was $18.7 \%$ in plants with absence of $\mathrm{K}$.

$\mathrm{Ca}$ is an important element for the formation of the cell wall and membrane, in addition to participating in the processes of cell division and multiplication (Hawkesford et al., 2012; Alcántar et al., 2016). The first two phases of fruit growth consist of cell proliferation and thickening (Agustí, 2010), so a Ca deficiency affects these processes. The above explains the results found in this study regarding the lower weight and size of fruits of the -Ca treatment. In another study, Esref et al. (2008) found that Ca deficiency decreased the average fruit weight from 16.24 to $14.43 \mathrm{~g}$ when not applying this element, as well as a $34 \%$ decrease in fruit yield per plant, which represents the same effect found in this investigation.

\section{Physicochemical characteristics of the fruit}

The results associated with the physicochemical quality of the fruit showed significant differences $(p<0.05)$ in all the variables evaluated (Figure 1). For the total soluble solids content ( ${ }^{\circ}$ Brix), the lowest value was observed in the $-\mathrm{K}$ treatment $(15.21 \pm 2.62)$, which represented a decrease of $17.73 \%$ with respect to the control $(18.49 \pm 0.87)$, while the fruits of the -Ca treatment presented an increase of $21.36 \%(22.44 \pm 1.05)$, without finding significant statistical difference between the other treatments (Figure 1a). On the other hand, the titratable acidity decreased in the $-\mathrm{K}$ and $-\mathrm{Mg}$ treatments by $45 \%(0.22 \pm 0.03)$ and $37.5 \%(0.25 \pm 0.02)$, respectively, with respect to the control $(0.4 \pm 0.01)$, on the other hand, The $-\mathrm{P}$ and $-\mathrm{Ca}$ treatments were statistically the same (Figure $1 \mathrm{~b}$ ). The same trend was found for the $\mathrm{pH}$ of the fruit, where the $-\mathrm{K}$ treatment resulted in the lowest value, presenting a reduction of $10.20 \%$ (4.84 \pm 0.12$)$ with respect to the control (5.39 \pm 0.07 ), without finding differences with the other treatments (Figure 1c).

The decrease in the total soluble solids content $\left({ }^{\circ} \mathrm{Brix}\right)$ in fruits with macronutrient deficiency ( $\mathrm{P}$ and $\mathrm{K}$ ) is explained due to the accumulation of photosynthates in the leaves, as well as the low mobilization towards the fruits, as explained above. The reduction of ${ }^{\circ} \mathrm{Brix}$ in fruits with $\mathrm{K}$ deficiency was also reported by Soliman et al. (2018), finding a decrease of $10.34 \%$ with respect to the control. On the other hand, the increase in the amount of total soluble solids in the fruits of the -Ca treatment is explained by the fact that the plants resulted with the smallest size and quantity of fruits $(18.52 \pm 1.49$ and $5.50 \pm 0.70)$, causing an effect of sugar concentration in them due to the greater amount of photosynthates accumulated in the fruit per unit of weight.

The effects found in terms of physicochemical characteristics have been reported in other fruits, such as orange (Citrus spp.) (Quaggio et al., 2011) and apple (Malus domestica) (Nava et al., 2008). 


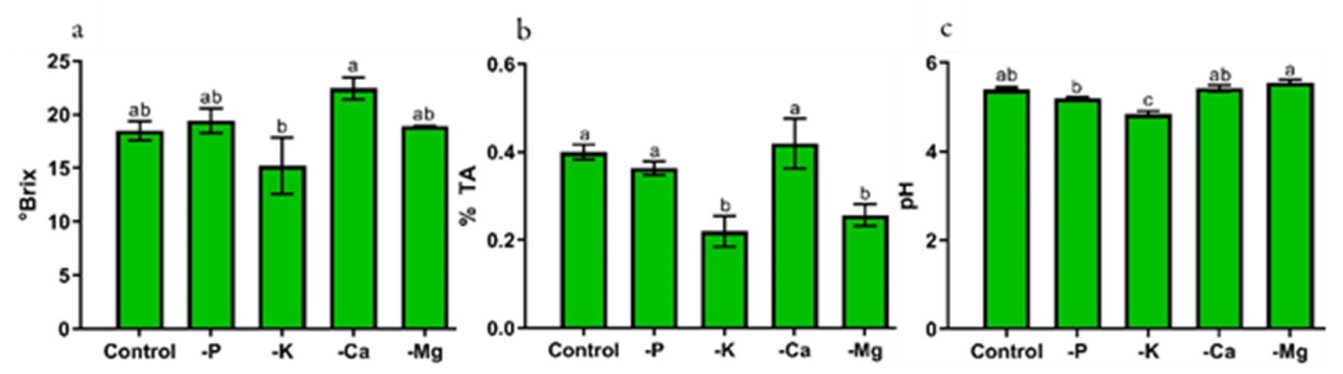

Figure 1. Total soluble solids content ( $\left.{ }^{\circ} \mathrm{Brix}\right)(\mathrm{a})$, titratable acidity (b), and $\mathrm{pH}$ (c) of fig tree fruits with macronutrient deficiencies. Values are the mean of treatments $(n=3)$. Bars represent the standard deviation of mean.

Different letters in each column means that the treatments were statistically different (Tukey, $p<0.05$ ).

\section{Chromatic characteristics of the fruits}

Results of chromatic characteristics of the fruits showed significant differences $(p<0.05)$ in all the variables (Table 2). In the case of pulp color, the highest value of $L^{*}$ was observed in the -K treatment $(35.66 \pm$ 0.98), however, no significant differences were found between the other treatments. The aforementioned indicates greater luminosity in the fruit pulp as they are subject to $\mathrm{K}$ deficiency. On the other hand, results indicated that the lowest values in $b^{*}$ were found in the $-\mathrm{P},-\mathrm{Mg}$, and -Ca treatments $(3.26 \pm 0.51,4.70 \pm 0.14$ and $5.20 \pm 0.14)$ respectively, compared to the control $(7.55 \pm 0.49)$. The same trend was found in $C^{*}$, since the lowest values were obtained in the -Ca and -P treatments ( $9.35 \pm 0.77$ and $9.66 \pm 0.51$ ), with respect to the control $(12.10 \pm 0.14)$. On the contrary, in $h^{*}$, it is only observed that the -P treatment obtained the lowest value $(19.90 \pm 3.11)$, compared to the other treatments that did not show a significant difference.

Table 2. Chromatic characteristics in pulp and peel of fig tree fruits with macronutrient deficiencies

\begin{tabular}{|c|c|c|c|c|c|c|}
\hline Treatment & $L^{*}$ & $a^{*}$ & $b^{*}$ & $C^{*}$ & $h$ & View \\
\hline \multicolumn{7}{|c|}{ Pulp } \\
\hline Control & $30.86 \pm 1.28 \mathrm{ab}$ & $8.83 \pm 1.05 \mathrm{~ns}$ & $7.55 \pm 0.49 a$ & $12.10 \pm 0.14 \mathrm{a}$ & $36.93 \pm 3.81 \mathrm{a}$ & \\
\hline$-\mathrm{P}$ & $30.06 \pm 1.96 b$ & $9.10 \pm 0.51 \mathrm{~ns}$ & $3.26 \pm 0.51 \mathrm{~d}$ & $9.66 \pm 0.51 b$ & $19.90 \pm 3.11 \mathrm{~b}$ & \\
\hline$-\mathrm{K}$ & $35.66 \pm 0.98 a$ & $9.99 \pm 0.79 \mathrm{~ns}$ & $6.30 \pm 0.00 \mathrm{ab}$ & $11.23 \pm 0.50 \mathrm{ab}$ & $36.93 \pm 4.78 a$ & \\
\hline$-\mathrm{Ca}$ & $33.05 \pm 1.76 \mathrm{ab}$ & $7.75 \pm 1.06 \mathrm{~ns}$ & $5.20 \pm 0.14 b c$ & $9.35 \pm 0.77 b$ & $32.23 \pm 4.42 \mathrm{a}$ & \\
\hline$-\mathrm{Mg}$ & $33.93 \pm 2.34 \mathrm{ab}$ & $8.35 \pm 0.35 \mathrm{~ns}$ & $4.70 \pm 0.14 c$ & $10.20 \pm 1.13 \mathrm{ab}$ & $35.40 \pm 5.12 \mathrm{a}$ & \\
\hline \multicolumn{7}{|c|}{ Peel } \\
\hline Control & $34.26 \pm 3.29 \mathrm{~ns}$ & $-0.55 \pm 0.21 \mathrm{a}$ & $19.31 \pm 4.18 \mathrm{~ns}$ & $19.40 \pm 4.27 \mathrm{~ns}$ & $94.52 \pm 2.73 \mathrm{~ns}$ & \\
\hline$-\mathrm{P}$ & $31.46 \pm 0.91 \mathrm{~ns}$ & $-1.63 \pm 0.04 \mathrm{ab}$ & $16.97 \pm 2.22 \mathrm{~ns}$ & $17.03 \pm 2.17 \mathrm{~ns}$ & $94.13 \pm 2.82 \mathrm{~ns}$ & \\
\hline$-\mathrm{K}$ & $33.91 \pm 2.97 \mathrm{~ns}$ & $-1.96 \pm 0.33 b$ & $20.35 \pm 3.31 \mathrm{~ns}$ & $20.47 \pm 3.34 \mathrm{~ns}$ & $95.63 \pm 0.34 \mathrm{~ns}$ & \\
\hline$-\mathrm{Ca}$ & $32.06 \pm 1.66 \mathrm{~ns}$ & $-0.79 \pm 0.19 \mathrm{ab}$ & $13.32 \pm 3.14 \mathrm{~ns}$ & $13.46 \pm 3.30 \mathrm{~ns}$ & $95.19 \pm 4.25 \mathrm{~ns}$ & \\
\hline$-\mathrm{Mg}$ & $35.29 \pm 3.53 \mathrm{~ns}$ & $-1.6 \pm 0.70 \mathrm{ab}$ & $23.20 \pm 5.08 \mathrm{~ns}$ & $20.51 \pm 2.80 \mathrm{~ns}$ & $91.27 \pm 3.09 \mathrm{~ns}$ & \\
\hline
\end{tabular}

Values are the mean of treatments $(n=3) \pm$ standard deviation. Different letters in each column means that the treatments were statistically different (Tukey, $p<0.05$ ).

On the contrary, the chromatic characteristics of the peel indicate that only significant differences were found in $\mathrm{a}^{*}$, where only the $-\mathrm{K}$ treatment was less than the other treatments $(-1.96 \pm 0.33)$, among which no differences were found for this characteristic (Table 2).

The previous results are similar to those reported by Nava et al. (2008), who found that, by increasing the doses of $\mathrm{K}$, the value of $\mathrm{a}^{*}$ also increased, as well as a reduction of $\mathrm{b}^{*}$ in apple fruits.

Currently, the effects of macronutrient deficiency on the color parameters of fig fruits are unknown. The main compounds that provide the color to the fruits are carotenoids (orange-yellow colors), anthocyanins 
(purple-reddish colors), lycopene (red color), and chlorophylls (green color) (Lancaster et al., 1997). In a study carried out on plants of Medicago sativa, an increase in the levels of shikimic acid was found (Rakhmankulova et al., 2003), which is a precursor of some compounds, such as anthocyanins and flavonoids; therefore, by increasing the concentration of these compounds in the fruit, the color parameters change. The differences in color parameters between nutritional deficiency treatments can be explained due to the above.

Botanically, the fig is not a true fruit, but a set of achenes grouped inside a receptacle (peel), therefore, this set of fruits is considered infrutescence (Syconium), while the shell corresponds to a modified part of the stem, where the true fruits are found in the pulp (Crisosto et al., 2011). Due to the above, it is explained that the chromatic parameters were affected in the fig pulp, without finding differences in the peel, where only a significant difference was found for $\mathrm{a}^{*}$, which can be explained due to the alteration of the chlorophylls in fruit peels.

\section{Concentration of minerals in fruit}

Concentration of elements in fruits was significantly affected $(p<0.05)$ for all the treatments with macronutrient deficiency (Table 3). The concentration of $\mathrm{N}$ in the fruits was lower in the $-\mathrm{P},-\mathrm{Mg},-\mathrm{K}$, and $-\mathrm{Ca}$ treatments, with reductions compared to the control of $51.4 \%, 51.4 \%, 45 \%$, and $32.6 \%$, respectively. The $-\mathrm{P}$, $\mathrm{Ca}$, and $-\mathrm{Mg}$ treatments did not affect the concentration of other elements, however, the $-\mathrm{K}$ treatment caused a higher concentration of $\mathrm{Mg}$ in the fruit (Table 3).

The increase in the concentration of $\mathrm{Mg}$ in fruits with $\mathrm{K}$ deficiency is explained by the interaction of the $\mathrm{K}^{+} / \mathrm{Mg}^{++}$ions in the plant, explained by Farhat et al. (2016) and Guo et al. (2016). This effect has been reported in different plants, such as Cymbopogon citratus (Capato et al., 2019) and Saccharum officinarum (Rhodes et al., 2018).

Table 3. Macroelement concentrations of fig tree fruits with macronutrient deficiencies

\begin{tabular}{|c|c|c|c|c|c|}
\hline \multirow{2}{*}{ Treatment } & \multicolumn{5}{|c|}{ Macroelements (\% of dry weight) } \\
\cline { 2 - 6 } & $\mathrm{N}$ & $\mathrm{P}$ & $\mathrm{K}$ & $\mathrm{Ca}$ & $\mathrm{Mg}$ \\
\hline Control & $2.82 \pm 0.29 \mathrm{a}$ & $0.17 \pm 0.02 \mathrm{ab}$ & $0.79 \pm 0.08 \mathrm{a}$ & $0.23 \pm 0.01 \mathrm{ab}$ & $0.07 \pm 0.01 \mathrm{~b}$ \\
\hline$-\mathrm{P}$ & $1.37 \pm 0.15 \mathrm{~b}$ & $0.15 \pm 0.01 \mathrm{~b}$ & $0.74 \pm 0.12 \mathrm{a}$ & $0.28 \pm 0.03 \mathrm{ab}$ & $0.07 \pm 0.01 \mathrm{ab}$ \\
\hline$-\mathrm{K}$ & $1.55 \pm 0.31 \mathrm{~b}$ & $0.23 \pm 0.02 \mathrm{a}$ & $0.38 \pm 0.05 \mathrm{~b}$ & $0.29 \pm 0.01 \mathrm{a}$ & $0.10 \pm 0.01 \mathrm{a}$ \\
\hline$-\mathrm{Ca}$ & $1.90 \pm 0.42 \mathrm{~b}$ & $0.22 \pm 0.01 \mathrm{a}$ & $0.84 \pm 0.07 \mathrm{a}$ & $0.21 \pm 0.02 \mathrm{~b}$ & $0.09 \pm 0.02 \mathrm{ab}$ \\
\hline$-\mathrm{Mg}$ & $1.37 \pm 0.12 \mathrm{~b}$ & $0.20 \pm 0.02 \mathrm{ab}$ & $0.84 \pm 0.05 \mathrm{a}$ & $0.27 \pm 0.03 \mathrm{ab}$ & $0.07 \pm 0.01 \mathrm{~b}$ \\
\hline
\end{tabular}

Values are the mean of treatments $(n=3) \pm$ standard deviation. Different letters in each column means that the treatments were statistically different (Tukey, $p<0.05$ ).

Regarding the concentration of microelements in fruits, significant differences were found between the treatments for the concentration of $\mathrm{Fe}, \mathrm{Mn}, \mathrm{Zn}$, and $\mathrm{Cu}$. In the case of the concentration of $\mathrm{Fe}$ in the fruits, higher levels were found in the $-\mathrm{K}$ treatment $(77.69 \pm 24.0 \mathrm{ppm})$ compared to the control $(36.82 \pm 2.7 \mathrm{ppm})$, which represents an increase of $111 \%$ in the concentration of this element. Fe also increased in the fruits of the -Ca treatment by $50.9 \%$ ( $55.56 \pm 10.5 \mathrm{ppm})$. The same trend was found in the Mn concentrations for the $-\mathrm{K}$ and -Ca treatments, which increased by $248.37(12.89 \pm 3.0 \mathrm{ppm})$ and $201.62 \%(11.16 \pm 2.1 \mathrm{ppm})$ with respect to the control $(3.70 \pm 0.3 \mathrm{ppm})$. Finally, the $\mathrm{Cu}$ concentration increased $81.1 \%$ in the $-\mathrm{P}$ treatment $(3.91 \pm 0.1$ $\mathrm{ppm})$, as well as $72.2 \%$ in the $-\mathrm{K}$ treatment $(3.72 \pm 0.3 \mathrm{ppm})$, the above with respect to the control $(2.16 \pm 0.3$ ppm) (Table 4). 
Garza-Alonso CA et al. (2020). Not Bot Horti Agrobo 48(3):1585-1599

Table 4. Microelement concentrations of fig tree fruits with macronutrient deficiencies

\begin{tabular}{|c|c|c|c|c|c|}
\hline \multirow{2}{*}{ Treatment } & \multicolumn{5}{|c|}{ Microelements (ppm) } \\
\cline { 2 - 6 } & Fe & B & Mn & Zn & $\mathrm{Cu}$ \\
\hline Control & $36.82 \pm 2.7 \mathrm{~b}$ & $19.16 \pm 2.6 \mathrm{~ns}$ & $3.70 \pm 0.3 \mathrm{~b}$ & $8.38 \pm 2.1 \mathrm{ab}$ & $2.16 \pm 0.3 \mathrm{c}$ \\
\hline$-\mathrm{P}$ & $39.54 \pm 5.1 \mathrm{~b}$ & $20.21 \pm 2.5 \mathrm{~ns}$ & $3.38 \pm 0.4 \mathrm{~b}$ & $10.99 \pm 2.0 \mathrm{ab}$ & $3.91 \pm 0.1 \mathrm{a}$ \\
\hline$-\mathrm{K}$ & $77.69 \pm 24.0 \mathrm{a}$ & $22.56 \pm 3.3 \mathrm{~ns}$ & $12.89 \pm 3.0 \mathrm{a}$ & $11.68 \pm 2.7 \mathrm{ab}$ & $3.72 \pm 0.3 \mathrm{ab}$ \\
\hline$-\mathrm{Ca}$ & $55.56 \pm 10.5 \mathrm{ab}$ & $19.38 \pm 3.0 \mathrm{~ns}$ & $11.16 \pm 2.1 \mathrm{a}$ & $14.88 \pm 2.1 \mathrm{a}$ & $2.58 \pm 0.1 \mathrm{c}$ \\
\hline$-\mathrm{Mg}$ & $44.38 \pm 4.4 \mathrm{~b}$ & $21.85 \pm 3.0 \mathrm{~ns}$ & $4.02 \pm 0.4 \mathrm{~b}$ & $7.72 \pm 3.3 \mathrm{~b}$ & $2.93 \pm 0.4 \mathrm{bc}$ \\
\hline
\end{tabular}

Values are the mean of treatments $(n=3) \pm$ standard deviation. Different letters in each column means that the treatments were statistically different (Tukey, $p<0.05$ ).

The aforementioned effects are explained because the plant tends to balance ionic charges inside the cells, so that, as there is a low concentration of $\mathrm{K}^{+}$and $\mathrm{Ca}^{++}$ions, a greater accumulation of $\mathrm{Fe}^{++}, \mathrm{Mn}^{++}$ions occurs, $\mathrm{Zn}^{++}$and $\mathrm{Cu}^{++}$, all of them cations, as well as $\mathrm{K}^{+}$and $\mathrm{Ca}^{++}$(Mengel et al., 2001). Results found in the present investigation coincide with those reported by Garza-Alonso et al. (2019), where similarities were observed in the behavior of minerals in the tissues of the fig tree in the absence of macronutrients.

\section{Total phenolic compounds}

Concentration of total phenolic compounds, flavonoids, and condensed tannins in the fig pulp resulted with a significant statistical difference $(p<0.05)$ between treatments with macronutrient deficiency (Table 5$)$. The lowest concentration of soluble phenols was obtained in the $-\mathrm{K}$ treatment $\left(457.61 \pm 50.70 \mathrm{mgGAE} \mathrm{\textrm {kg } ^ { - 1 }}\right)$, which represented a decrease of $24.4 \%$ compared to the control $\left(605.75 \pm 61.99 \mathrm{mgGAE} \mathrm{kg}{ }^{-1}\right)$. This effect was also reported by Gaaliche et al. (2019), who found a lower concentration of phenols in fig fruits without the application of $\mathrm{K}$, with reductions of $14.3 \%$ compared to plants fertilized with this element. On the other hand, Galieni et al. (2015) found no difference in the concentration of total soluble phenols between Lactuca sativa plants with P deficiency and the control treatment. The same effect was reported by Davarpanah et al. (2017) in pomegranate fruits (Punica granatum), where no significant difference was found between plants with and without application of Ca.

On the other hand, the bound phenolic compounds increased in the - $\mathrm{Ca}$, $-\mathrm{P}$, and $-\mathrm{K}$ treatments by $66.2 \%$ $\left(142.43 \pm 1.11 \mathrm{mg} \mathrm{GAE} \mathrm{kg}^{-1}\right), 43.5 \%\left(122.97 \pm 17.04 \mathrm{mg} \mathrm{GAE} \mathrm{kg}^{-1}\right)$, and $30.1 \%(111.41 \pm 16.51 \mathrm{mg} \mathrm{GAE}$ $\left.\mathrm{kg}^{-1}\right)$, respectively, compared to the control $\left(85.68 \pm 6.80 \mathrm{mg} \mathrm{GAE} \mathrm{kg}^{-1}\right)$. This can be explained due to the location of phenolic compounds bound to the cell wall (Acosta et al., 2013), which increased due to the absence of macronutrients, possibly as a protection mechanism for cells. Galieni et al. (2015) also reported the increase in the concentration of bound phenolic compounds in plants subjected to $\mathrm{P}$ deficiency, where these compounds increased by $20 \%$ in lettuce plants (Lactuca sativa).

Regarding the concentration of soluble phenolic compounds in the peel of fig fruits, a similar trend was observed as above, where the soluble phenolic compounds in the peel decreased in the $-\mathrm{Mg},-\mathrm{K}$, and $-\mathrm{P}$ treatments by $27.4 \%\left(278.35 \pm 22.83 \mathrm{mg} \mathrm{GAE} \mathrm{kg}^{-1}\right), 26.6 \%\left(282.26 \pm 27.89 \mathrm{mg} \mathrm{GAE} \mathrm{kg}^{-1}\right)$, and $23.9 \%(291.86$ $\left.\pm 26.77 \mathrm{mg} \mathrm{GAE} \mathrm{kg}^{-1}\right)$, respectively, compared to the control (383.30 $\left.\pm 16.42 \mathrm{mg} \mathrm{GAE} \mathrm{kg}^{-1}\right)$. For fruit peel, bound phenolic compounds decreased in the $-\mathrm{Mg}$ and $-\mathrm{K}$ treatments by $41.6 \%$ (40.78 $\pm 9.17 \mathrm{mg} \mathrm{GAE} \mathrm{kg^{-1 }}$ ) and $21.5 \%$ ( $\left.54.83 \pm 1.72 \mathrm{mg} \mathrm{GAE} \mathrm{kg}^{-1}\right)$, however, an increase of $66.6 \%$ was found in the -Ca treatment (116.43 $\left.\pm 8.59 \mathrm{mg} \mathrm{GAE} \mathrm{kg}^{-1}\right)$, all of the above with respect to the control $\left(69.86 \pm 15.00 \mathrm{mg} \mathrm{GAE} \mathrm{kg}^{-1}\right)$ (Table 5).

The concentration of soluble flavonoids in pulp was lower in the $-\mathrm{K}$, $-\mathrm{Ca}$, and $-\mathrm{Mg}$ treatments, where Ca deficiency negatively affected $78.69 \%$, followed by $\mathrm{K}$ with $48.94 \%$, and $\mathrm{Mg} 33.29 \%$, the above compared with the control. Trejo et al. (2019) reported the same effect, where no difference in flavonoid content was found between Brassica juncea plants with and without P deficiency. In the research by Gaaliche et al. (2019) a $48 \%$ reduction in the concentration of total flavonoids was reported when $\mathrm{K}$ was not applied to fig plants, as happened in this work. The concentration of bound flavonoids was negatively affected in all the treatments with absence of macronutrients $(-\mathrm{P},-\mathrm{K},-\mathrm{Ca}$, and $-\mathrm{Mg})$, where the lowest concentration was found in the $-\mathrm{K}$ 
treatment $\left(31.39 \pm 2.94 \mathrm{mg} \mathrm{CatE} \mathrm{kg}^{-1}\right)$, followed by treatments $-\mathrm{Ca}\left(34.22 \pm 3.02 \mathrm{mg} \mathrm{CatE} \mathrm{kg}{ }^{-1}\right),-\mathrm{Mg}(36.99$ $\left.\pm 4.91 \mathrm{mg} \mathrm{CatE} \mathrm{kg}^{-1}\right)$, and $-\mathrm{P}\left(38.33 \pm 4.91 \mathrm{mg} \mathrm{CatE} \mathrm{kg}^{-1}\right)$. In the case of fruit peel, soluble and bound flavonoids were not detected (Table 5).

Table 5. Phenolic compounds, flavonoids, and condensed tannins of fig tree fruits with macronutrient deficiencies

\begin{tabular}{|c|c|c|c|c|c|c|}
\hline \multirow[t]{2}{*}{ Treatment } & \multicolumn{2}{|c|}{$\begin{array}{l}\text { Phenolic compounds } \\
\left(\mathrm{mgGAE} \mathrm{kg}^{-1}\right)\end{array}$} & \multicolumn{2}{|c|}{$\begin{array}{c}\text { Flavonoids } \\
(\mathrm{mgCatE} \mathrm{kg})\end{array}$} & \multicolumn{2}{|c|}{$\begin{array}{l}\text { Condensed tannins } \\
\left.(\mathrm{mgCatE} \mathrm{kg})^{-1}\right)\end{array}$} \\
\hline & Soluble & Bound & Soluble & Bound & Soluble & Bound \\
\hline \multicolumn{7}{|c|}{ Pulp } \\
\hline Control & $605.75 \pm 61.99 \mathrm{a}$ & $85.68 \pm 6.80 \mathrm{~b}$ & $238.28 \pm 29.40 \mathrm{a}$ & $51.99 \pm 2.89 \mathrm{a}$ & $762.58 \pm 26.07 \mathrm{c}$ & nd \\
\hline$-\mathrm{P}$ & $613.88 \pm 30.93 \mathrm{a}$ & $122.97 \pm 17.04 \mathrm{ab}$ & $184.12 \pm 11.82 \mathrm{ab}$ & $38.33 \pm 4.91 b$ & $986.09 \pm 7.66 \mathrm{a}$ & nd \\
\hline$-\mathrm{K}$ & $457.61 \pm 50.70 \mathrm{~b}$ & $111.41 \pm 16.51 \mathrm{ab}$ & $121.65 \pm 5.87 c$ & $31.39 \pm 2.94 b$ & $788.79 \pm 10.97 \mathrm{c}$ & nd \\
\hline$-\mathrm{Ca}$ & $521.02 \pm 27.77 \mathrm{ab}$ & $142.43 \pm 1.11 \mathrm{a}$ & $50.76 \pm 22.02 \mathrm{~d}$ & $34.22 \pm 3.02 b$ & $937.56 \pm 24.28 \mathrm{ab}$ & nd \\
\hline$-\mathrm{Mg}$ & $511.06 \pm 54.84 \mathrm{ab}$ & $92.08 \pm 11.57 \mathrm{~b}$ & $158.94 \pm 8.36 \mathrm{bc}$ & $36.99 \pm 4.91 b$ & $906.14 \pm 21.97 \mathrm{~b}$ & nd \\
\hline \multicolumn{7}{|c|}{ Peel } \\
\hline Control & $383.30 \pm 16.42 \mathrm{a}$ & $69.86 \pm 15.00 \mathrm{~b}$ & nd & nd & $458.15 \pm 5.98 \mathrm{bc}$ & nd \\
\hline$-\mathrm{P}$ & $291.86 \pm 26.77 \mathrm{~b}$ & $60.46 \pm 10.33 \mathrm{bc}$ & nd & nd & $422.52 \pm 26.08 c$ & nd \\
\hline$-\mathrm{K}$ & $282.26 \pm 27.89 b$ & $54.83 \pm 1.72 b c$ & nd & nd & $557.66 \pm 34.91 \mathrm{a}$ & nd \\
\hline$-\mathrm{Ca}$ & $385.09 \pm 2.83 \mathrm{a}$ & $116.43 \pm 8.59 a$ & nd & nd & $539.84 \pm 24.05 \mathrm{ab}$ & nd \\
\hline$-\mathrm{Mg}$ & $278.35 \pm 22.83 b$ & $40.78 \pm 9.17 c$ & nd & nd & $455.05 \pm 11.59 \mathrm{bc}$ & nd \\
\hline
\end{tabular}

Values are the mean of treatments $(n=3) \pm$ standard deviation. Different letters in each column means that the treatments were statistically different (Tukey, $p<0.05$ ). nd: not detected.

The condensed tannins were increased in the $-\mathrm{P},-\mathrm{Ca}$, and $-\mathrm{Mg}$ treatments with respect to the control. The increase in condensed tannins in the $-\mathrm{P},-\mathrm{Ca}$, and $-\mathrm{Mg}$ treatments were $29.3 \%, 22.9 \%$ and $18.8 \%$, respectively. This is explained because the Shikimic Acid pathway can end in the synthesis of anthocyanins or condensed tannins (He et al., 2015). As there is a deficiency of P, plants tend to accumulate anthocyanins in the tissues (Chandra and Karmoker, 2011). In the case of figs with light-colored peels (ripening green or yellow), the content of anthocyanins has not been detected in various studies (Harzallah et al., 2016; Vallejo et al., 2011); on the contrary, this study found an increase in condensed tannins in fruits of the -P treatment, which can be explained by what was previously described. Bound condensed tannins were not detected in pulp and peel of fruits (Table 5).

\section{Antioxidant capacity}

The antioxidant capacity of fig fruits was different between treatments $(p<0.05)$ for the DPPH, ABTS and FRAP assays (Table 6). In all the evaluations, the soluble portion was the one with the highest levels of antioxidant capacity. For DPPH, the -Ca and -P treatments reported the highest levels of antioxidant capacity, with increases of 12.8\% (3265.1 $\left.\pm 30.4 \mu \mathrm{molTE} \mathrm{kg}^{-1}\right)$ and 9.0\% (3127.6 $\left.\pm 11.0 \mu \mathrm{molTE} \mathrm{kg}{ }^{-1}\right)$, with respect to the control $\left(2844.8 \pm 35.4 \mu \mathrm{molTE} \mathrm{kg}^{-1}\right)$. In the case of the bound portion, the fruits with Ca deficiency had a higher antioxidant capacity, with an increase of $40.83 \%$ (788.4 \pm 14.3$)$ compared to the control $(559.8 \pm 30.7)$ (Table 6). 
Garza-Alonso CA et al. (2020). Not Bot Horti Agrobo 48(3):1585-1599

Table 6. Antioxidant capacity (DPPH, ABTS, and FRAP) of fig tree fruits with macronutrient deficiencies

\begin{tabular}{|c|c|c|c|c|c|c|}
\hline \multirow{2}{*}{ Treatment } & \multicolumn{2}{|c|}{ DPPH $\left(\mu\right.$ molTE kg $\left.{ }^{-1}\right)$} & \multicolumn{2}{|c|}{ ABTS $\left(\mu\right.$ molTE $\left.\mathrm{kg}^{-1}\right)$} & \multicolumn{2}{|c|}{ FRAP $\left(\mu\right.$ molTE $\left.\mathrm{kg}^{-1}\right)$} \\
\hline & Soluble & Bound & Soluble & Bound & Soluble & Bound \\
\hline \multicolumn{7}{|c|}{ Pulp } \\
\hline Control & $2844.8 \pm 35.4 \mathrm{c}$ & $559.8 \pm 30.7 \mathrm{~b}$ & $4337.1 \pm 41.4 b$ & $646.9 \pm 23.6 \mathrm{c}$ & $983.3 \pm 55.3 \mathrm{c}$ & $120.4 \pm 42.0 \mathrm{c}$ \\
\hline$-\mathrm{P}$ & $3127.6 \pm 11.0 \mathrm{~b}$ & $599.2 \pm 13.6 \mathrm{~b}$ & $4501.8 \pm 36.1 \mathrm{a}$ & $740.8 \pm 21.1 \mathrm{~b}$ & $697.6 \pm 65.7 \mathrm{~d}$ & $693.4 \pm 33.5 \mathrm{ab}$ \\
\hline$-\mathrm{K}$ & $2528.1 \pm 35.1 \mathrm{~d}$ & $585.3 \pm 21.6 \mathrm{~b}$ & $3202.7 \pm 20.8 \mathrm{~d}$ & $886.2 \pm 18.9 \mathrm{a}$ & $1226.1 \pm 65.8 \mathrm{~b}$ & $669.7 \pm 43.8 \mathrm{ab}$ \\
\hline$-\mathrm{Ca}$ & $3265.1 \pm 30.4 \mathrm{a}$ & $788.4 \pm 14.3 \mathrm{a}$ & $3904.1 \pm 17.0 \mathrm{c}$ & $841.4 \pm 17.1 \mathrm{a}$ & $686.0 \pm 38.8 \mathrm{~d}$ & $560.2 \pm 56.8 b$ \\
\hline$-\mathrm{Mg}$ & $2732.5 \pm 23.1 \mathrm{c}$ & $647.2 \pm 37.5 b$ & $4366.4 \pm 65.0 \mathrm{~b}$ & $694.7 \pm 20.3 \mathrm{bc}$ & $1453.1 \pm 45.0 \mathrm{a}$ & $726.5 \pm 17.7 \mathrm{a}$ \\
\hline \multicolumn{7}{|c|}{ Peel } \\
\hline Control & $1396.7 \pm 26.3 b$ & $511.3 \pm 20.7 \mathrm{a}$ & $2257.2 \pm 23.5 b$ & $487.8 \pm 61.3 \mathrm{~b}$ & $2561.9 \pm 47.1 \mathrm{c}$ & $196.5 \pm 56.3 c$ \\
\hline$-\mathrm{P}$ & $1371.6 \pm 72.3 b$ & $352.1 \pm 27.3 \mathrm{~b}$ & $2147.1 \pm 21.4 b$ & $329.9 \pm 42.1 \mathrm{c}$ & $3354.6 \pm 61.6 \mathrm{~b}$ & $226.5 \pm 29.3 c$ \\
\hline$-\mathrm{K}$ & $1002.7 \pm 61.4 \mathrm{c}$ & $389.5 \pm 23.6 b$ & $1241.7 \pm 31.2 \mathrm{c}$ & $372.9 \pm 20.8 \mathrm{bc}$ & $3821.8 \pm 115.1 \mathrm{a}$ & $395.2 \pm 20.1 \mathrm{~b}$ \\
\hline$-\mathrm{Ca}$ & $1977.6 \pm 12.5 \mathrm{a}$ & $561.0 \pm 22.2 \mathrm{a}$ & $2803.3 \pm 24.1 \mathrm{a}$ & $695.8 \pm 24.1 \mathrm{a}$ & $2539.7 \pm 36.1 \mathrm{c}$ & $429.5 \pm 12.8 \mathrm{ab}$ \\
\hline$-\mathrm{Mg}$ & $966.6 \pm 71.6 c$ & $264.6 \pm 32.8 c$ & $2173.8 \pm 54.2 b$ & $259.1 \pm 54.2 \mathrm{c}$ & $3251.9 \pm 27.5 b$ & $470.0 \pm 12.9 \mathrm{a}$ \\
\hline
\end{tabular}

Values are the mean of treatments $(n=3) \pm$ standard deviation. Different letters in each column means that the treatments were statistically different (Tukey, $\mathrm{p}<0.05)$.

The ABTS assay showed a similar trend, since the fruits of the $-\mathrm{P}$ treatment presented the highest antioxidant capacity $\left(4501.8 \pm 36.1 \mu \mathrm{molTE} \mathrm{kg}{ }^{-1}\right)$, which represented an increase of $3.8 \%$ compared to the control $\left(4337.1 \pm 41.4 \mu \mathrm{molTE} \mathrm{kg}^{-1}\right)$, while the lowest values were reported in the $-\mathrm{K}(3202.7 \pm 20.8)$ and $-\mathrm{Ca}$ $\left(3904.1 \pm 17.0 \mu \mathrm{molTE} \mathrm{kg}^{-1}\right)$ treatments compared to the $-\mathrm{P}$ treatment. The ABTS antioxidant capacity in the bound compounds had an inverse behavior to the soluble compounds, because it increased in the - $\mathrm{K}$ and -Ca treatments by 37 and $30 \%$, respectively, compared to the control (Table 6).

Fruit peel and pulp resulted similar for antioxidant capacity, since the $-\mathrm{K}$ treatment indicated the lowest values of antioxidant capacity in the soluble portion $\left(1241.7 \pm 31.2 \mu \mathrm{molTE}_{\mathrm{kg}}{ }^{-1}\right)$, while the -Ca treatment presented the highest antioxidant capacity values for the soluble and bound portion, with increases of $24.2 \%$ $\left(2803.3 \pm 24.1 \mu \mathrm{molTE} \mathrm{kg}^{-1}\right)$ and $42.7 \%\left(695.8 \pm 24.1 \mu \mathrm{molTE} \mathrm{kg}^{-1}\right)$, respectively, compared to the values obtained in control $\left(2257.2 \pm 23.5\right.$ and $\left.487.8 \pm 61.3 \mu \mathrm{molTE} \mathrm{kg}{ }^{-1}\right)$. In contrast, the lowest values in the bound portion were found in the $-\mathrm{Mg}$ treatments $\left(259.1 \pm 54.2 \mu \mathrm{molTE} \mathrm{kg}^{-1}\right),-\mathrm{P}\left(329.9 \pm 42.1 \mu \mathrm{molTE} \mathrm{kg}^{-1}\right)$, and $-\mathrm{K}$ $\left(372.9 \pm 20.8 \mu \mathrm{molTE} \mathrm{kg}^{-1}\right)$, with respect to the control $\left(487.8 \pm 61.3 \mu \mathrm{molTE} \mathrm{kg}{ }^{-1}\right)$ (Table 6).

The FRAP assay found an increase in the antioxidant capacity of the pulp in the soluble portion of $47.8 \%$ for the $-\mathrm{Mg}$ treatment $\left(1453.1 \pm 45.0 \mu \mathrm{molTE} \mathrm{kg}^{-1}\right)$ and $24.7 \%$ for $-\mathrm{K}\left(1226.1 \pm 65.8 \mu \mathrm{molTE} \mathrm{kg}{ }^{-1}\right)$, with respect to the control $\left(983.3 \pm 55.3 \mu \mathrm{molTE} \mathrm{kg}^{-1}\right)$, while the $-\mathrm{Ca}$ and $-\mathrm{P}$ treatments decreased by 30 and $29 \%$, respectively, compared to the control $\left(983.3 \pm 55.3 \mu\right.$ molTE $\left.\mathrm{kg}^{-1}\right)$ (Table 6).

In the case of fruit pulp and peel bound compounds, higher antioxidant capacity values were found for all macronutrient deficiency treatments $(-\mathrm{P},-\mathrm{K},-\mathrm{Ca}$, and $-\mathrm{Mg})$. For pulp, the values were reported in the following order: $-\mathrm{Mg}>-\mathrm{P}>-\mathrm{K}>-\mathrm{Ca}$, with increases of $503.4 \%\left(726.5 \pm 17.7 \mu \mathrm{molTE} \mathrm{kg}^{-1}\right), 475.9 \%(693.4 \pm 33.5$ $\left.\mu \mathrm{molTE} \mathrm{kg}^{-1}\right), 456.22 \%\left(669.7 \pm 43.8 \mu \mathrm{molTE} \mathrm{kg}{ }^{-1}\right)$, and 365\% (560.2 $\left.\pm 56.8 \mu \mathrm{molTE} \mathrm{kg}^{-1}\right)$, respectively, compared to the control $\left(120.4 \pm 42.0 \mu \mathrm{molTE} \mathrm{kg}{ }^{-1}\right)$. On the other hand, increases in fruit peel were reported in the following order: $-\mathrm{Mg}>-\mathrm{Ca}>-\mathrm{K}$, with increases of $139.2 \%$ (470.0 $\left.\pm 12.9 \mu \mathrm{molTE} \mathrm{kg}{ }^{-1}\right), 118.6 \%(429.5 \pm$ $\left.12.8 \mu \mathrm{molTE} \mathrm{kg}^{-1}\right)$, and $101.1 \%\left(395.2 \pm 20.1 \mu \mathrm{molTE} \mathrm{kg}{ }^{-1}\right)$, respectively, compared to the control $(196.5 \pm$ $56.3 \mu$ molTE kg $^{-1}$ ) (Table 6). 
In general, the soluble FRAP values were higher in peel, compared to pulp, for all the treatments evaluated. The above coincides with that reported by Guo et al. (2003) where a higher antioxidant capacity was found in the peel of different fruits, such as orange, pineapple, and banana. The FRAP antioxidant capacity in the soluble portion of peel increased in the $-\mathrm{K},-\mathrm{P}$, and $-\mathrm{Mg}$ treatments by $49.2,31.0$, and $27.0 \%$, respectively, compared to the control $(256.2 \pm 4.71)$.

The reduction in antioxidant capacity using the DPPH assay is explained by the low amount of total phenolic compounds in fruits with absence of K. On the other hand, Kumar et al. (2007) reported increases in the free radical $\mathrm{H}_{2} \mathrm{O}_{2}$ in Morus alba fruits subjected to $\mathrm{P}$ deficiency; this effect could explain the increase in $\mathrm{DPPH}$ antioxidant capacity in the fruits of the -P treatment of the present study. On the other hand, Guo et al. (2018) reported an increase of $15 \%$ in the antioxidant capacity in plants of Brassica oleracea with Ca deficiency. Singh et al. (2011) found greater antioxidant capacity in Dacus carota plants with Ca deficiency, which increased by $50 \%$, determined by the ORAC method for water-soluble compounds, which can be compared with the DPPH assay used in the present study. A similar trend was found in the case of antioxidant capacity in shell.

The increase in ABTS antioxidant capacity was also reported by Galieni et al. (2015) when finding a $25 \%$ increase in ABTS antioxidant capacity in Lactuca sativa plants without application of $P$. The same effect was reported by Singh et al. (2011) in Dacus carota using the ORAC test for fat soluble compounds, where an increase of $17.64 \%$ was observed, which can be compared with the ABTS test. Another study by Ahmad et al. (2016) reported increases in $\mathrm{H}_{2} \mathrm{O}_{2}$ levels and increased lipid peroxidation in Cicer arietinum plants subjected to $\mathrm{Ca}$ deficiency, which could explain the results found in our research. $\mathrm{Ca}$ is an important element in plant metabolism, since one of its main functions is as a component of the cell membrane, which favors its integrity (Hawkesford et al., 2012). Due to the above, Ca deficiency promotes oxidative stress in plant cells. This effect was widely described by Nieves et al. (2018).

Michalska et al. (2016) reported an increase in FRAP in K-deficient Solanum tuberosum plants, as in the present study. FRAP antioxidant capacity also decreased in Brassica oleracea plants with absence of Ca (Guo et al., 2018). The increase in FRAP antioxidant capacity for the bound portion can be explained by a response of the plant to avoid cell damage by free radicals, increasing the antioxidant capacity of compounds bound to the cell wall.

\section{Conclusions}

The absence of macronutrients in fig plants during vegetative and reproductive growth affected performance, reducing the size, weight, and number of fruits, while plants with $\mathrm{N}$ deficiencies did not produce fruits. Likewise, macronutrient deficiencies affected the physicochemical quality of the fruits, with reductions in ${ }^{\circ} \mathrm{Brix}, \mathrm{pH}$, and AT. It is important to mention that the total phenolic compounds (soluble + bound) increased in the -P and -Ca treatments, which was reflected in increases in antioxidant capacities in the DPPH, $\mathrm{ABTS}$, and FRAP tests. The $-\mathrm{K}$ treatment registered the lowest values of phenolic compounds and, therefore, of antioxidant capacity. Based on the results, it is concluded that each element had a specific effect on fruit yield and quality.

\section{Authors' Contributions}

Conceptualization: CAGA and EOS; Data curation: GNM and EOS; Funding acquisition: AGD, Investigation: REVA and ALJ; Methodology: JIGL, AGD and ALJ; Project administration: EOS; Supervision: JIGL, REVA and ALJ; Writing - original draft: CAGA; Writing - review and editing: GNM and EOS. All authors read and approved the final manuscript. 


\section{Acknowledgements}

This work was supported by the Consejo Nacional de Ciencia y Tecnología (CONACYT) through scholarship 864110 awarded for the Master of Science studies of Carlos Alberto Garza-Alonso.

\section{Conflict of Interests}

The authors declare that there are no conflicts of interest related to this article.

\section{References}

Acosta EBA, Gutiérrez UJA, Serna SSO (2013). Bound phenolics in foods: a review. Food Chemistry 152:46-55. http://doi.org/10.1016/j.foodchem.2013.11.093

Agustí M (2010). Fruticultura. $2^{\text {nd }}$ ed. Ed. Mundi-Prensa, Madrid, España pp 507. ISBN 978-84-8476-398-7.

Ahmad P, Abdel LAA, Abd AEF, Hashem A, Sarwat M, Anjum NA, Gucel S (2016). Calcium and potassium supplementation enhanced growth, osmolyte secondary metabolite production, and enzymatic antioxidant machinery in cadmium-exposed chickpea (Cicer arietinum L.). Frontiers in Plant Science 7:513. https://doi.org/10.3389/fpls.2016.00513

Alcántar GG, Trejo TLI, Fernández PL, Rodríguez MM (2016). Elementos esenciales. In: Alcántar GG, Trejo TLI, Gómez M (Eds). Nutrición de cultivos, $2^{\text {nd }}$ ed. Colegio de Postgraduados: México City, Méx., pp 23-55. ISBN: 978-607-715-324-5.

Alcántar GG, Sandoval VM (1999). Handbook chemical analysis of vegetal tissue. Especial Publication No. 10. Mexican Society of Soil Science (In Spanish). Chapingo, Estado de México, México.

AOAC (2000). Vitamin and other nutrient. In: Hoerwitz W (Ed). Official Methods of Analysis of the Association of Official Analytical Chemists International, $17^{\text {th }}$ ed. AOAC International: Gaithersburg, MD, USA.

Badgujar SB, Patel VV, Bandivdekar AH, Mahajan RT (2014). Traditional uses, phytochemistry and pharmacology of Ficus carica: A review. Pharmaceutical Biology 52(11):1487-1503. https://doi.org/10.3109/13880209.2014.892515

Bremner JM (1965). Total nitrogen. In: Norman AG (Ed). Methods for Soil Analysis. Part 2. Chemical and microbiological properties. American Society of Agronomy, Inc. Madison, Wisconsin, USA, pp 1149-1178.

Capato LT, Mendoca FMS, Paes MLV, Souza GY, Pires PJA, Franca LK (2019). Visual symptoms of macronutrient and boron deficiency in Cymbopogon citratus. Journal of Plant Nutrition 13:1430-1438. https://doi.org/10.1080/01904167.2019.1628974

Chandra SB, Karmoker JL (2011). Effects of phosphorus deficiency on accumulation of biochemical compounds in lentil (Lens culinaris M.) Bangladesh Journal of Botany 40(1):23-27. https://doi.org/10.3329/bjb.v40i1.7992

ColorHexa (2019). Color Encyclopedia: Information and Conversion. Computer Software. Retrieved 2019 January 31 from https://www.colorhexa.com

Commission Internationale De L'ecleirage (2004). CIE 15: Technical Report: Colorimetry, Commission Internationale De L'ecleirage, $3^{\text {rd }}$ ed.; CIE: Vienna, Austria.

Crisosto H, Ferguson L, Bremer V, Stover E, Colelli G (2011). Fig (Ficus carica L.) In: Yahia EM (Ed). Postharvest biology and technology of tropical and subtropical fruits. Woodhead Publishing, Elsevier. Cambridge, U.K., pp 134-158. https://doi.org/10.1533/9780857092885.134

Crisosto CH, Bremer V, Ferguson L, Crisosto GM (2010). Evaluating quality attributes of four fresh fig (Ficus carica L.) cultivars harvested at two maturity stages. HortScience 45(4):707-710. https://doi.org/10.21273/HORTSCI.45.4.707

Davarpanah S, Tehranifar A, Abadía J, Val J, Davarynejad G, Aran M, Khorassani R (2017). Foliar calcium fertilization reduces fruit cracking in pomegranate (Punica granatum cv. Ardestani). Scientia Horticulturae 230:86-91. https://doi.org/10.1016/j.scienta.2017.11.023

Deepa P, Sowndhararajan K, Kim S, Jin PS (2018). A role of Ficus species in the management of diabetes mellitus: A review. Journal of Ethnopharmacology 215:210-232. https://doi.org/10.1016/j.jep.2017.12.045 
Esref I M, Aksoy U, Okur B, Ongun A, Tepecik M (2008). Effect of calcium-based fertilization on dried fig (Ficus carica L. cv. Sarilop) yield and quality. Scientia Horticulturae 118(4):308-312. https://doi.org/10.1016/j.scienta.2008.06.024

Farhat N, Elkhouni A, Zorrig W, Smaoui A, Abdelly C, Rabhi M (2016). Effects of magnesium deficiency on photosynthesis and carbohydrate partitioning. Acta Physiologiae Plantarum 145. https://doi.org/10.1007/s11738-016-2165-z

Food and Agriculture Organization (FAO) Statistical Yearbook. Agricultural production. Retrieved 2019 December 12 from http://www.fao.org/faostat/es/\#data/QC

Gaaliche B, Ladhari A, Zarrelli A, Ben MM (2019). Impact of foliar potassium fertilization on biochemical composition and antioxidant activity of fig (Ficus carica L.). Scientia Horticulturae 253:111-119. https://doi.org/10.1016/j.scienta.2019.04.024

Galieni A, Di Mattia C, Gregorio M, Speca S, Mastrocola D, Pisante M, Stagnari F (2015). Effects of nutrient deficiency and abiotic environmental stresses onyield, phenolic compounds and antiradical activity in lettuce (Lactuca sativa L.). Scientia Horticulturae 187:93-101. http://doi.org/10.1016/j.scienta.2015.02.036

Garza-Alonso CA, Olivares-Sáenz E, Gutiérrez-Díez A, Vázquez-Alvarado RE, López-Jiménez A (2019) Visual symptoms, vegetative growth, and mineral concentration in fig tree (Ficus carica L.) under macronutrient deficiencies. Agronomy 9(12):787. https://doi.org/10.3390/agronomy9120787

Guo C, Yang L, Wei J, Li Y, Xu J, Jiang Y (2003). Antioxidant activities of peel, pulp and seed fractions of common fruits as determined by FRAP assay. Nutrition Research 23(13):1719-1726. http://doi.org/10.1016/S02715317(03)00184-2

Guo L, Zhu Y, Wang F (2018). Calcium sulfate treatment enhances bioactive compounds and antioxidant capacity in broccoli sprouts during growth and storage. Postharvest Biology and Technology 139:12-19. https://doi.org/10.1016/j.postharvbio.2018.01.010

Guo W, Nazim H, Liang Z, Yang D (2016). Magnesium deficiency in plants: An urgent problem. The Crop Journal 4(2):83-91. https://doi.org/10.1016/j.cj.2015.11.003

Harzallah A, Bhouri AM, Amri Z, Soltana H, Hammami M (2016). Phytochemical content and antioxidant activity of different fruit parts juices of three figs (Ficus carica L.) varieties grown in Tunisia. Industrial Crops and Products 83:255-267. http://doi.org/10.1016/j.indcrop.2015.12.043

Hawkesford M, Horst W, Kichey T, Lambers H, Schjoerring J, Skrumsager I, White P (2012). Functions of macronutrients. In: Marschner H (Ed). Marschner's mineral nutrition of higher plants, $3^{\text {rd }}$ ed. Academic Press, London, UK, pp 135-189. https://doi.org/10.1016/C2009-0-63043-9

He M, Tian H, Luo X, Qi X, Chen X (2015). Molecular progress in research on fruit astringency. Molecules 20:14341451. http://doi.org/10.3390/molecules20011434

Holstein H, Crisosto GM, Crisosto CH (2017). Fertirigation with potassium increase size and yield in fresh fig growing in California. Acta Horticulturae 1173:177-182. https://doi.org/10.17660/ActaHortic.2017.1173.30

Karthika KS, Rashmi I, Parvathi MS (2018). Biological functions, uptake and transport of essential nutrients in relation to plant growth. In: Hasanuzzaman M, Fujita M, Oku H, Nahar K, Hawrylak B (Eds). Plant nutrients and abiotic stress tolerance. Springer Nature, Gateway East, Singapore, pp 1-49. https://doi.org/10.1007/978-981-10-90448

Kathpalia R, Bhatla SC (2018). Plant Mineral Nutrition. In: Bhatla SC, Lal MA (Eds). Plant physiology, development and metabolism; Springer Nature, Gateway East, Singapore, pp 37-81. https://doi.org/10.1007/978-981-132023-1

Kobayashi NI, Saito T, Iwata N, Ohmae Y, Iwata R, Tanoi K, Nakanishi M (2013). Leaf senescence in rice due to magnesium deficiency mediated defect in transpiration rate before sugar accumulation and chlorosis. Physiologia Plantarum 148(4):490-501. https://doi.org/10.1111/ppl.12003

Kumar TR, Kumar P, Nand SP (2007). Oxidative stress and antioxidant responses in young leaves of mulberry plants grown under nitrogen, phosphorus or potassium deficiency. Journal of Integrative Plant Biology 49(3):313-322. https://doi.org/10.1111/j.1672-9072.2006.00358.x

Lancaster JE, Lister CE, Reay PF, Triggs CM (1997). Influence of pigment composition on skin color in a wide range of fruit and vegetables. Journal of American Society of Horticultural Science 122(4):594-598.

López-Contreras JJ, Zavala-García F, Urías-Orona V, Martínez-Ávila GCG, Rojas R, Nino-Medina G (2015). Chromatic, phenolic and antioxidant properties of sorghum bicolor genotypes. Notulae Botanicae Horti Agrobotanici Cluj Napoca 43(2):366-370. https://doi.org/10.15835/nbha4329949 
Mendoza CVM, Pineda PJ, Vargas CJM, Hernández AE (2019). Nutrition of fig (Ficus carica L.) under hydroponics and greenhouse conditions. Journal of Plant Nutrition 11:1350-1365. https://doi.org/10.1080/01904167.2019.1609510

Mengel K, Kirkby EA, Kosegarten H, Appel T (2001). Principles of plant nutrition $5^{\text {th }}$ ed. Springer, Dordrecht, NL. https://doi.org/10.1007/978-94-010-1009-2

Michalska A, Wojdylo A, Bogucka B (2016). The influence of nitrogen and potassium fertilisation on the content of polyphenolic compounds and antioxidant capacity of coloured potato. J. Journal of Food Composition and Analysis 47:69-75. http://doi.org/10.1016/j.jfca.2016.01.004

Mota RMJ, Rocha PLG (2014). Physical and quality characteristics of jupi pineapple fruits on macronutrient and boron deficiency. Natural Resources 5(8):359-366. http://doi.org/10.4236/nr.2014.58034

Nava G, Roque A, Ribeiro G (2008). Nitrogen and potassium fertilization affect apple fruit quality in Southern Brazil. Communications in Soil Science and Plant Analysis 39(1):96-107. http://doi.org/10.1080/00103620701759038

Nieves CM, López DM, Ródenas R, Martínez V, Rubio F, Rivero R (2018). Critical responses to nutrient deprivation: a comprehensive review on the role of ROS and RNS. Environmental and Experimental Botany 161:64-85. https://doi.org/10.1016/j.envexpbot.2018.10.039

Pandey R (2015). Mineral nutrition of plants. In: Bahadur B, Rajam MV, Sahijram L, Krishnamurthy KV (Eds). Plant biology and biotechnology: Volume 1: Plant diversity: Organization, function, and improvement. Springer, India, pp 499-538. https://doi.org/10.1007/978-81-322-2286-6_20

Papadopoulos AP, Bar-Tal A, Silber A, Saha UK, Raviv K (2008). Inorganic and synthetic organic components of soilless culture and potting mixes. In: Raviv M, Lieth JH (Eds). Soilless Culture, Theory and Practices. Elsevier, Amsterdam, NL., pp 505-543. ISBN: 978-0-444-52975-6

Quaggio JA, Junior DM, Boaretto RM (2011). Sources and rates of potassium for sweet orange production. Scientia Agricola 68(3):369-375. http://doi.org/10.1590/S0103-90162011000300015

Rhodes R, Miles N, Charles HJ (2018). Interactions between potassium, calcium and magnesium in sugarcane grown on two contrasting soils in South Africa. Field Crops Research 225:1-11. https://doi.org/10.1016/j.fcr.2018.01.001

Sevil KS, Ertan E, Seferoglu S (2007). Effect of different nutrient solution formulations on morphological and biochemical characteristics of nursery fig trees grown in substrate culture. Scientia Horticulturae 113(2):20-27. https://doi.org/10.1016/j.scienta.2007.01.032

Singh DP, Beloy J, Mclnerney JK, Dar L (2011). Impact of boron, calcium and genetic factors on vitamin C, carotenoids, phenolic acids, anthocyanins and antioxidant capacity of carrots (Daucus carota) Food Chemistry 132(3):11611170. https://doi.org/10.1016/j.foodchem.2011.11.045

Soliman SS, Alebidi AI, Al-Obeed A, Saif AM (2018). Effect of potassium fertilizer on fruit quality and mineral composition of fig (Ficus carica L. cv. Brown Turkey). Pakistan Journal of Botany 50(5):1753-1758.

Trejo TLI, Estrada OE, Gómez MFC, Becker C, Krumbein A, Schwarz D (2019). Flavonoid, nitrate and glucosinolate concentrations in brassica species are differentially affected by photosynthetically active radiation, phosphate and phosphite. Frontiers in Plant Science 10:371. http://doi.org/10.3389/fpls.2019.00371

United States Department of Agriculture (FAO) (2019). Agricultural Marketing Service. Specialty Crops. Retrieved 2019 December $\quad 15$ from https://www.marketnews.usda.gov/mnp/fv-navbyCom?navClass $=$ VEGETABLES\&navType $=$ byComm

Vallejo F, Marín JG, Tomás BFA (2011). Phenolic compound content of fresh and dried figs (Ficus carica L.). Food Chemistry 130(3):485-492. https://doi.org/10.1016/j.foodchem.2011.07.032
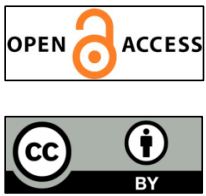

The journal offers free, immediate, and unrestricted access to peer-reviewed research and scholarly work. Users are allowed to read, download, copy, distribute, print, search, or link to the full texts of the articles, or use them for any other lawful purpose, without asking prior permission from the publisher or the author.

License - Articles published in Notulae Botanicae Horti Agrobotanici Cluj-Napoca are Open-Access, distributed under the terms and conditions of the Creative Commons Attribution (CC BY 4.0) License. (c) Articles by the authors; UASVM, Cluj-Napoca, Romania. The journal allows the author(s) to hold the copyright/to retain publishing rights without restriction. 